\title{
Overexpression of NtERF5, a New Member of the Tobacco Ethylene Response Transcription Factor Family Enhances Resistance to Tobacco mosaic virus
}

\author{
Ute Fischer and Wolfgang Dröge-Laser \\ Albrecht-von-Haller Institut, Universität Göttingen, Untere Karspüle 2, D-37073 Göttingen, Germany
}

Submitted 4 March 2004. Accepted 28 June 2004.

\begin{abstract}
A new member of the tobacco (Nicotiana tabacum) AP2/ERF (ethylene response factor) transcription factor family, designated $N t$ ERF5, has been isolated by yeast one-hybrid screening. In vitro, recombinant $N t$ ERF5 protein weakly binds GCC box cis-elements, which mediate pathogen-regulated transcription of several $P R$ (pathogenesis related) genes. NtERF5 transcription is transiently activated by wounding, by infection with the bacterial pathogen Pseudomonas syringae, as well as by inoculation with Tobacco mosaic virus (TMV). In contrast, NtERF5 transcription is not enhanced after application of salicylic acid, jasmonic acid, or ethylene. Constitutive overexpression of NtERF5 (ERF5-Oex) under control of the $35 \mathrm{~S}$ promoter results in no visible alterations in plant growth or enhanced resistance to Pseudomonas infection. Furthermore, no constitutive expression of $\boldsymbol{P R}$ genes has been observed. In contrast, ERF5-Oex plants show enhanced resistance to TMV with reference to reduced size of local hypersensitive-response lesions and impaired systemic spread of the virus. Since, in TMV-infected ERF5-Oex plants, the viral RNA accumulates only up to 10 to $30 \%$ of the wild-type level, we suggest that NtERF5-regulated gene expression is controlling resistance to viral propagation. Previous research has demonstrated that overexpression of $E R F$ genes enhances resistance to bacterial and fungal pathogens. Here, we provide further evidence that resistance to viral infection can be engineered by overexpression of $E R F$ transcription factors.
\end{abstract}

Additional keywords: TMV resistance.

Plants have to respond to environmental changes, such as biotic and abiotic stresses, in order to reprogram gene expression in an appropriate manner. Pathogen-responsive gene regulation has been shown to be mediated by specific transcription factors. Members of the bZIP (Jakoby et al. 2002), WRKY (Eulgem et al. 2000), Myb (Daniel et al. 1999), or AP2/ERF (ethylene response factor) (Riechmann and Meyerowitz 1998)

Corresponding author: W. Dröge-Laser; E-mail: wdroege@gwdg.de; Telephone +49-(0)551-39-19816; Fax: +49-(0)551-39-7820.

Current address of U. Fischer: IPK-Gatersleben, Corrensstrasse 3, D06466 Gatersleben, Germany.

Nucleotide sequence data is available in the GenBank database under accession number AY655738.

This article is in the public domain and not copyrightable. It may be freely reprinted with customary crediting of the source. The American Phytopathological Society, 2004. transcription factors have been implicated in pathogen-induced transcription. In particular, AP2/ERF transcription factors belong to one of the largest plant transcription factor families, comprising 145 members in the model plant Arabidopsis thaliana (Sakuma et al. 2002). They are characterized by a conserved DNA-binding domain, the AP2/ERF domain, which is 57 to 66 amino acids in size (Okamuro et al. 1997). Interestingly, this DNA-binding domain (Okamuro et al. 1997; Hao et al. 1998) is found only in the plant kingdom, which suggests plant-specific functions (Riechmann and Meyerowitz 1998). Allen and associates (1998) have analyzed the 3D solution structure of an AP2/ERF domain and have found that it consists of a threestranded antiparallel $\beta$-sheet and an $\alpha$-helix packed approximately parallel to the $\beta$-sheet. The $\beta$-sheet interacts with specific motifs located inside the major groove of the DNA helix.

The founding member of AP2/ERF transcription factor family, Arabidopsis APETALA2 (AP2) is a well-defined transcription factor regulating flower development (Riechmann and Meyerowitz 1998). Whereas the AP2-like proteins harbor two AP2/ERF DNA-binding domains, the RAV1-like subfamily contains one AP2/ERF and a B3 DNA-binding domain (Kagaya et al. 1999; Sakuma et al. 2002). A third subfamily is characterized by one AP2/ERF domain only. Based on DNA-binding data, this group has been subdivided into dehydration-responsive element-binding (DREB)-like proteins, which interact with the dehydration-responsive, or cold-repeat, element (consensus sequence TACCGACAT) (Liu et al. 1998; Stockinger et al. 1997) and the EREBP-like (ethylene responsive element binding protein) proteins binding the GCC box (consensus sequence AGCCGCC) (Ohme-Takagi and Shinshi 1995; Sakuma et al. 2002). Recently, the latter group has been renamed as ERF. The ERF founding members, the tobacco proteins $N t$ ERF1 to $N t \mathrm{ERF} 4$, have been isolated, due to their binding to GCC boxes found in several PR promoters (Ohme-Takagi and Shinshi 1995; Ohta et al. 2000). NtERF1 to NtERF4 are transcriptionally activated by ethephon, a compound leading to the release of the plant hormone ethylene. Therefore, $N t \mathrm{ERF} 1$ to $N t \mathrm{ERF} 4$ have been implicated in ethylene signaling. However, the biological function of these factors is not, as yet, well-characterized.

Up to now, ERF transcription factors have been described in different plant species, such as tomato (Zhou et al. 1997), rice (Dubouzet et al. 2003), Catharanthus roseus (van der Fits and Memelink 2000), and Arabidopsis thaliana (Fujimoto et al. 2000; Ohta et al. 2001). In those cases in which functions have been assigned, these proteins have been found to be participating in plant responses to abiotic and biotic stresses (Kizis et al. 2001; Ohme-Takagi et al. 2000; Riechmann and Meyerowitz 1998). As examples, Arabidopsis DREB1 and DREB2 are involved in drought and cold stress response, ORCA3, isolated 
from Catharanthus roseus, regulates genes in jasmonic acid (JA)-induced secondary metabolism (van der Fits and Memelink 2000), and tomato Pti4, Pti5, and Pti6 regulate $P R$ genes (Wu et al. 2002; Zhou et al. 1997). Following Pseudomonas infection, Pti4 is phosphorylated by the Pto kinase, which is thought to mediate transcriptional activation of $P R$ genes (Gu et al. 2000).

Participating in pathogen-induced signaling networks, molecules like salicylic acid (SA) are involved in mediating local defense responses and establishing systemic acquired resistance (SAR) (Klessig et al. 2000). Ethylene in combination with JA also mediates pathogen responses in a SA-independent pathway. Depending on the pathogen, different pathways are triggered, leading to the activation of defined sets of target genes. For example, resistance to the necrotrophic fungus Botrytis cinerea utilizes ethylene/JA signaling networks, and accordingly, overexpression of the Arabidopsis ERF1 transcription factor enhances resistance to $B$. cinerea. In contrast, tolerance to Pseudomonas infection is decreased in ERF1overexpressing plants (Berrocal-Lobo et al. 2002). These findings support the model that cross-talk and cross-inhibition between pathogen-induced signaling pathways exist (Lorenzo et al. 2003). As it has been shown in a number of publications, overexpression of $E R F$ genes results in enhanced tolerance to pathogen attack (Berrocal-Lobo et al. 2002; Gu et al. 2002; He et al. 2001; Park et al. 2001; Shin et al. 2002). Whereas, overexpression of the tobacco Tsil gene leads to constitutive expression of $P R$ genes and a broad-spectrum resistance (Park et al. 2001), overexpression of Pti5 does not lead to constitutive $P R$ gene expression but accelerates pathogen-induced transcription (He et al. 2001). In summary, defined members of the ERF family seem to play specific roles in pathogen defense.

In this work, we describe a new member of the tobacco ERF family, designated NtERF5. Transcription of NtERF5 is enhanced after wounding and pathogen attack. Overexpression of NtERF5 does not lead to constitutive activation of $P R$ genes or enhanced resistance to Pseudomonas infection. In contrast, $N t$ ERF5-overexpressing plants suppress TMV proliferation, leading to enhanced viral resistance.

\section{RESULTS}

\section{Isolation of a new tobacco ERF gene.}

A yeast one-hybrid approach has been set up to isolate tobacco transcription factors that specifically bind promoter ciselements known to mediate pathogen-induced transcription (discussed below). Unexpectedly, a cDNA encoding a DNAbinding protein has been isolated, which does not bind to any of the well-characterized cis-elements used in this study, but interacts with a GC-rich stretch of DNA originating from the multiple cloning site of the pUK21 vector, which has been included in the one-hybrid screening construct due to the cloning strategy used. The isolated cDNA encodes a formerly undescribed member transcription factor of the ERF gene family, which bind GC-rich cis-elements, the so-called GCC boxes. Since ERF proteins have been shown to be involved in

Fig. 1. Amino acid sequence alignment of $N t$ ERF5 and related ERF (ethylene response factor) transcription factors. A, Amino acid comparison of $N t$ ERF5, NtERF1-4 (Ohme-Takagi and Shinshi 1995), Tsi (Park et al. 2001) from tobacco (Nt), Pti4, Pti5, and Pti6 (Zhou et al. 1997) from tomato (Lycopersicon esculentum [Le]), and ERF1 from Arabidopsis thaliana (At). Amino acid identity of $100 \%$ is marked by a black background; conservation of amino acids higher than 50\% are indicated in black on a gray background; similar amino acids are given in white on a gray background. B, Phylogenetic tree of the proteins given above. pathogen-regulated gene control, we characterized this clone in more detail. The full-length cDNA clone was isolated by $5^{\prime}-$ RACE (rapid amplification of cDNA ends) and was found to encode a 27-kDa protein (Fig. 1A). Despite the highly conserved AP2/ERF domain (Fig. 1A), this protein differs consid-

A

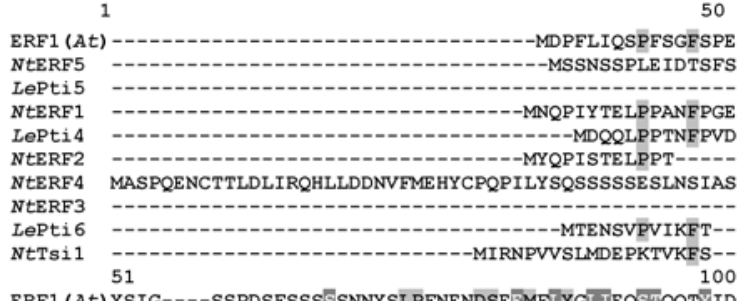
ERF1 (At) YSIG----SSPDSFSSSSISNNYSLPFNENDSE BMFIY GLIEQSTEQTIID NLERF5 HSNFFFLDQSPIILWDDDLFFNDPWFDDDQSPII PCNSEKDENHQVIEE LePti 5 ------------MVPTPQSDLPINENDSQ 3 MVLYEVINDANALNIPY NEERF1 FPVYRRNSSFSRIIIPCL TVT TWGDLPLKVDDEDMVIYTLIKDALNVG LePtI4 FPVYRRNSSFSRI IPCLTIKWGDLPLKVDDSEDMVIYGLLKDALSVGW SP NTERF2 ------S-FSSLMPCLTDTWGDLPLKVDDSEDMVIY GLISDALTAGW TP NERRF4 ELNNETFSFEPTLKYADIAQSSNLDISSFFNNSKTE DSFEFETKPNVSA NtERF3 - 3 LePti 6 -----QHIVITTNKHVFSËHNEK--SNS NtTsi1 -----QHIVKKNHVPEQNENSNFHSKFLQRVVRI ILTDADAJDSSDDE 101
ERF1 (At) SDS---------------------QDLPIKSVSSRKSEKS----YRGVF NTERF5 SSDNTIMSKGS--------SHGQELEEVTSEEEKEKEEEEKHY IGVR LePti5 LP----15

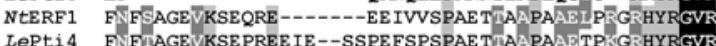
LEPt14 FNFIAGE VKSE PREE IE--SSPEFSPSPE TIAAPAADTPKGR HYRGVR NTERF4 ARISSNSPKQTSFKERKPSLNIAIPMKQQEVVQKVEVVPTEKKHYRGVRO

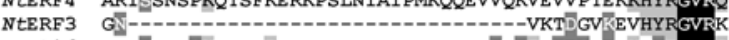

NERRF3 GN GRNTVRRVKRHVTEINLMPS-TKSIGDRKRSSVSPDSDVT RKKERGVRQ NtTsi 1 GCDDVRVKRHVTE INLMPS-PNLICE KKRRLVSPDTDVTRRKKERGVRQ

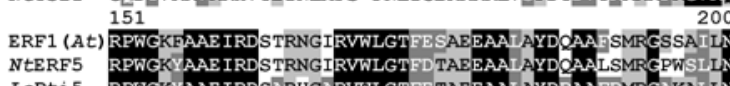
LePti 5 NtERF1 LePti 4 NTERF2 NTERF4 NEERF3 NtTsi 1 201
ERF1 (At) FSAERVQESLS--- 250 NEERF5 FPLEKVKKSL-----E---LePti5 FPSEIVNASVS----VD--------1 NTERF1 FPHRI GLNEP--1---E-1 NTERF2 FPHRI GLNEP-----E-NTERF4 FPLEVANFKQQDN---E-NTERF3 FPSPTENQSPSHSSTVESSSGENGVHAPPHAPLE LDLTRRLGSVA DAGGD NERRF3 FPSPTENQSPSHSSTVESSSGENGHAPPHAPLELDLTRRLGSVAMDGGD LePti6 FPVSTTAEVTVTVTE TE-----1

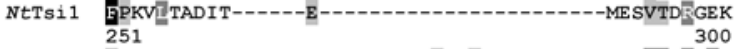

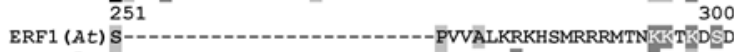
NtERF5 S------------------PAAVLK THKTRRVKHKR SSR--LePti5 [IN--------------------NNSDSSLNEVSSGTNDVFESRC--

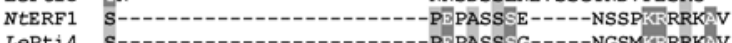

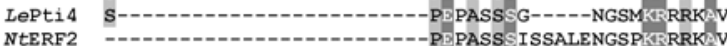
NEERF2 NTER 3 RMNEERF3 NCRRSGEVGYPIFHQQPTVAVLPNGQPVLLFDSLLRAGVVNRPQPYHVTP LePti 6 SE-----1

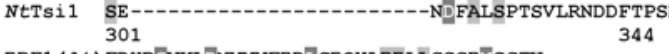
ERF1 (At) FDHRSVKLDNVVVFEDIIGEQYLELLIGSSETSGTW--------NTERF5 -KKKNKE THNVIVFEDLGAELLEELLMTSSOHSCRRD-------LePti5 - ---1---1 NTERF1 ATEKSEAVVESKSNVZT QTE CQVELLTRRH LLVS--------LePti4 QKCDG---BMASRSSV QVCCQIEQLTGVH LIVI-------NERF 2 AAKR NEERF4 APLTPSSWSAIWEGEDGKGIFEVPPLSPLSPHMAYSQLVMI-NEERF 3 MGFNGVNAGVGPTVSDSSS VEENQYDGKRGIDLDLNLAPPMEF $\begin{array}{ll}\text { LePti } 6 & \text { CEVDAFGFDVSLFRLPDFMTEKYYGDEFGE FDFDDFALEAR- } \\ \text { NtTsi } 1 & \text { CEVDAFGFDVSLFRLPE F CSEKYYGDEFGEFDFDDFALEAR- }\end{array}$

B

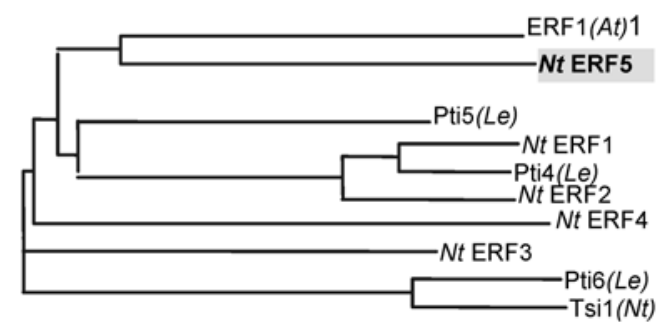


erably from the previously described tobacco ERF family members $N t$ ERF1 to NtERF4 (Ohme-Takagi and Shinshi 1995) and Tsil (King et al. 1996; Park et al. 2001) and was therefore designated NtERF5. The most closely related ERF is ERF1 from A. thaliana (Solano et al. 1998), showing an amino acid identity of $40 \%$ (Fig. 1B).

In vitro, $N t$ ERF5 binds GCC boxes with low affinity.

$N t$ ERF5 has been isolated by binding to an artificial GCrich sequence in a yeast one-hybrid screen. This sequence (TGG ATC CGA TAT CGC CGT GGC GGC CGC TCT) is

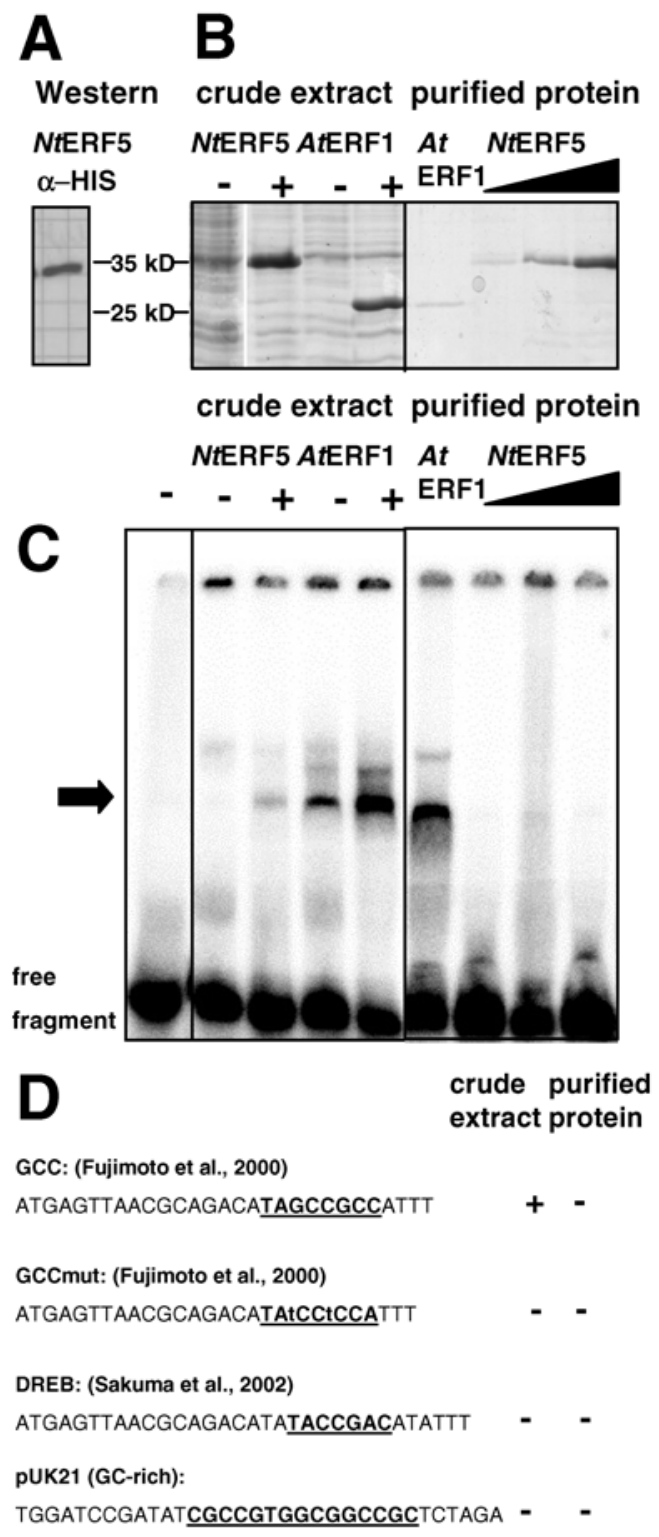

Fig. 2. DNA binding properties of $N t E R F 5$. Recombinant HIS-tagged $N t$ ERF5 protein was tested in electrophoretic mobility shift assays (EMSA). A, Recombinant HIS-NtERF5 protein was detected by Western analysis, using a HIS-specific antibody ( $\alpha$-His). B, Crude Escherichia coli extracts in which expression of HIS-NtERF5 or HIS-AtERF1 (Fujimoto et al. 2000) proteins were induced (+) or not induced (-) as well as purified HIS-tagged $A t$ ERF1 and $N t$ ERF5 proteins were analyzed by sodium dodecyl sulfate-polyacrylamide gel electrophoresis and Coomassie staining. C, The protein preparations shown in B were analyzed for DNA binding by means of EMSA, using the GCC-box fragment depicted in D. D, Summary of the EMSA performed with the indicated DNA fragments: +/DNA-binding results of crude bacterial extracts or purified NtERF5 protein, respectively. related to the typical GCC-box binding site, which is frequently found in $P R$ promoters. To analyze DNA binding, a His-tagged NtERF5 gene was expressed in Escherichia coli. Protein preparations were monitored by Western analysis and Coomassie staining (Fig. 2A and B). HIS-NtERF5 protein was compared with HIS-tagged AtERF1 protein, which has been extensively analyzed with respect to DNA binding (Allen et al. 1998). Under identical conditions, both proteins were purified, and DNA binding was studied using electrophoretic mobility shift assays (EMSA) (Fig. 2C). Whereas purified HIS-AtERF1 binds efficiently to GCC boxes, no binding of HIS-ERF5 was observed with several putative ERF target sites (Fig. 2D). However, with crude protein extract of $E$. coli expressing HIS-NtERF5, a weak GCC box-specific binding activity was observed that was not found using mutated GCC box (Fig. 2D, GCCmut). Several attempts to modify EMSA conditions failed to enhance DNA binding. Furthermore, binding sites of ERF-related DREB factors or the artificial GC-rich sequence that has been found to be an efficient binding site in yeast were not recognized by $N t$ ERF5 in vitro (Fig. 2D). We therefore conclude that the GCC box is a lowaffinity binding site in vitro. Most likely, posttranslational modifications or cofactors might enhance binding efficiency under in vivo conditions.

\section{NtERF5 transcription is induced}

by wounding and pathogen attack.

Many transcription factors belonging to the ERF family are involved in plant stress responses, in particular in pathogenregulated gene expression. Tissue-specific NtERF5 expression was found in parts of the flower but not in vegetative tissues (Fig. 3A). In contrast, NtERF5 transcription in leaves was strongly enhanced after infection with the bacterial pathogen Pseudomonas syringae. Depending on the type of interaction, using avirulent $P$. syringae pv. pisi (Tronchet et al. 2001) or virulent $P$. syringae pv. tabaci (Salch and Shaw 1988), we observed a rapid or retarded increase of NtERF5 steady-state transcript level, respectively (Fig. 3B). It has to be noted that wounding due to the injection of the bacteria rapidly and transiently induced NtERF5 transcription (Fig. 3B). Other wound treatments, like rubbing the leaf surface with Carborundum also led to NtERF5 induction (data not shown).

In contrast to the susceptible tobacco cultivar W38 (nn), a TMV-induced signaling cascade is triggered in the resistant tobacco cultivar Samsun $(\mathrm{NN})$, which harbors the $N$ resistance gene. Plant defense responses include the establishment of a hypersensitive response (HR) and the induction of $P R$ genes. Moreover, it is well-established that the $N$ gene-mediated plant defense is inactivated at elevated temperatures $\left(32^{\circ} \mathrm{C}\right)$ (Malamy et al. 1992). Therefore, TMV-induced plant defense response can easily be synchronized by a temperature shift experiment. Plants cultivated at $32^{\circ} \mathrm{C}$ were infected with TMV to allow systemic spread of the virus. After 4 days, temperature was shifted to $22^{\circ} \mathrm{C}$, and $N$ gene-mediated defense responses like enhanced NtERF5 transcription could be monitored in directly and systemically infected leaves (Fig. 3C). The PRla gene was used to monitor the onset of the plant resistance response (Cutt et al. 1988).

Tobacco transcription factors $N t$ ERF1to $N t E R F 4$ have been named with respect to their responsiveness to ethephon. In further experiments, ethephon, which releases ethylene after application, was used, (Ohme-Takagi and Shinshi 1995). However, NtERF5 was not induced following ethephon treatment (data not shown). Furthermore, signaling molecules like SA (Fig. 3D) or JA (data not shown) were not found to enhance $N t E R F 5$ transcription. The transcriptional responses observed 
A
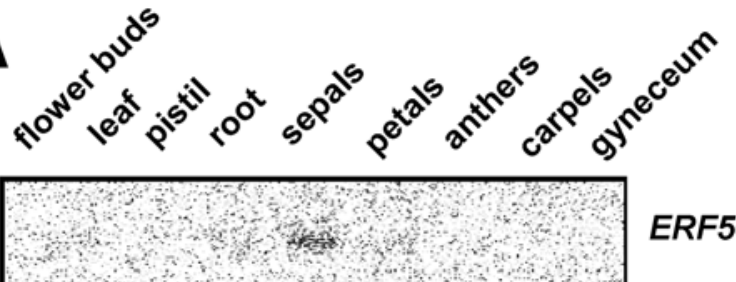

ERF5

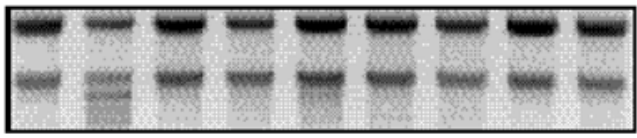

EtBr

B
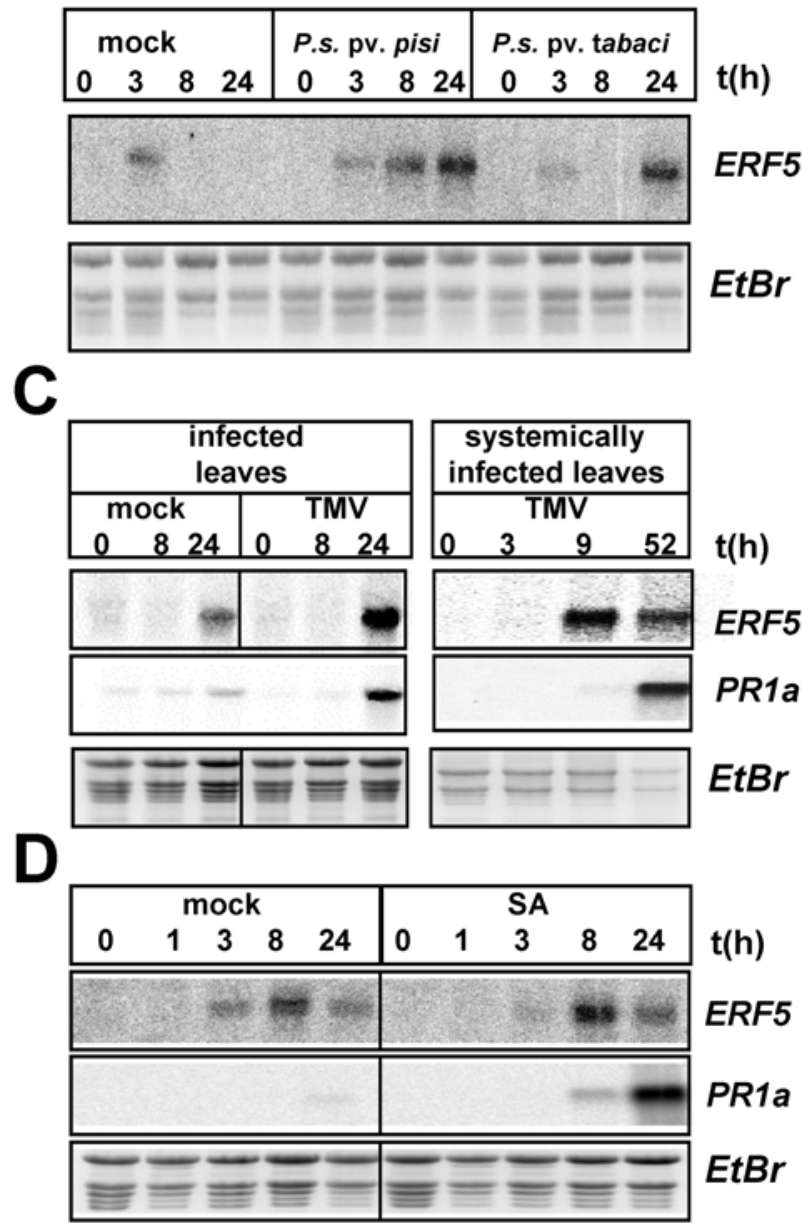

Fig. 3. Northern analysis of tobacco NtERF5 transcription. Total tobacco RNA was prepared from the indicated tissues and then fractionated by agarose gel electrophoresis. To determine its quality and relative amount between samples, RNA was stained with ethidium bromide (EtBr, lower panels). After Northern transfer, filters were probed with the radioactive DNA fragments indicated on the right. A, Tissue-specific expression of NtERF5. B, Pathogen-induced transcription of NtERF5. Tobacco leaves were infiltrated with Pseudommonas syringae pv. pisi (avirulent), $P$. syringae pv. tabaci (virulent), or $10 \mathrm{mM} \mathrm{MgCl}{ }_{2}$ solution (mock). Samples were harvested for RNA preparation at the timepoints indicated (in hours). C, Tobacco mosaic virus (TMV)-induced transcription of NtERF5. Tobacco Samsum (NN) plants were cultivated at $32^{\circ} \mathrm{C}$ and were inoculated with TMV. At permissive temperature, TMV is able to spread systemically. After 4 days, temperature was shifted to $22^{\circ} \mathrm{C}$. Tissue of directly infected leaves as well as tissue from systemically infected leaves was harvested at the timepoints indicated (hours after temperature shift). In order to assess the successful infection, PRla (Cutt et al. 1988) expression was monitored as a control. D, Tobacco leaf disks were floated on buffer with $1 \mathrm{mM}$ salicylic acid (SA). Tissue was harvested at the indicated timepoints (in hours after SA treatment). Transcription of the PRla gene (Cutt et al. 1988) was used as a control. All Northern blots have been repeated two to four times. both in mock- and hormone-treated samples are caused by wounding due to the cutting of leaf disks.

\section{Overexpression of $\mathrm{NtERF5}$ does not change plant defense responses}

toward the bacterial pathogen Pseudomonas syringae.

Ectopic overexpression of several $E R F$ genes resulted in stress-resistant transgenic plants (Berrocal-Lobo et al. 2002; $\mathrm{Gu}$ et al. 2002; He et al. 2001; Park et al. 2001; Shin et al. 2002). NtERF5 was overexpressed in the tobacco cultivar Wisconsin W38 under control of the Cauliflower mosaic virus (CaMV) 35S promoter (ERF5-Oex), and the level of overexpression was confirmed by Northern analysis (Fig. 4A). In comparison with wild type, no visible phenotypic alterations in plant growth were observed in ERF5-Oex transgenic tobacco lines. Since Pseudomonas infection induces NtERF5 transcription, we investigated whether constitutive NtERF5 expression increases resistance to bacterial infection. However, bacterial growth of virulent $P$. syringae pv. tabaci and avirulent $P$. syringae pv. pisi bacteria (Fig. 4B) and induction of

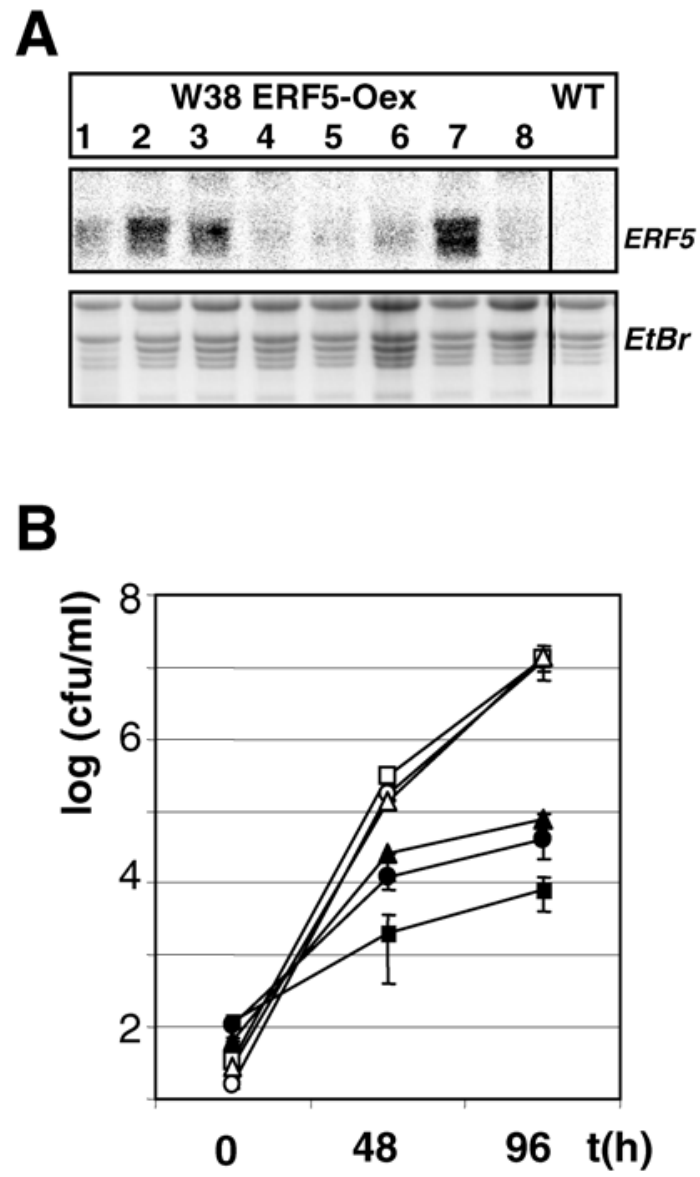

Fig. 4. Influence of overexpression of NtERF5 on resistance to Pseudomonas syringae infection. A, Overexpression of NtERF5 in tobacco Wisconsin W38 plants (W38-ERF5-Oex) was monitored by Northern analysis. Leaf RNAs from independent transgenic lines are numbered (1 to 8); WT $=$ wild type. Ethidium bromide staining $(\mathrm{EtBr})$ was used as a loading control (lower panel). B, Bacterial growth of $P$. syringae in wild-type (circle) and W38-ERF5-Oex plants. Leaves were infiltrated with $P$. syringae pv. pisi (avirulent, closed symbols) and P. syringae pv. tabaci (virulent, open symbols). After the timepoints indicated (in hours postinfection), bacteria were reisolated, plated, and counted. The results obtained with the transgenic lines W38-ERF5-Oex \#2 (squares) and W38-ERF5-Oex \#7 (triangles) are given. Each data point corresponds to the mean values of 20 independent infections obtained from three independent plants. $\mathrm{CFU}=$ colony forming units. 
typical $P R$ genes (data not shown) was comparable with that of wild type. The establishment of SAR in uninfected leaves was measured 10 days after challenge with $P$. syringae pv. pisi. However, with reference to bacterial growth of the virulent pathogen $P$. syringae pv. tabaci, NtERF5 overexpression has no effect on induction of SAR against re-infection with $P$. syringae (data not shown).

\section{Overexpression of $\mathrm{NtERF} 5$ enhances resistance to TMV.}

Furthermore, NtERF5 was overexpressed in the tobacco cultivar Samsun (NN), which harbors the $N$ resistance gene. Infection with TMV induces the formation of HR lesions. In order to quantify plant resistance responses, HR lesion size was determined according to Vernooij and associates (1994).

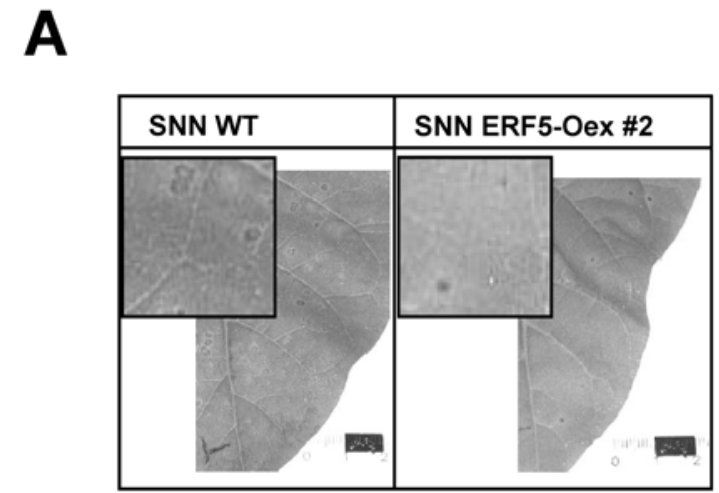

B

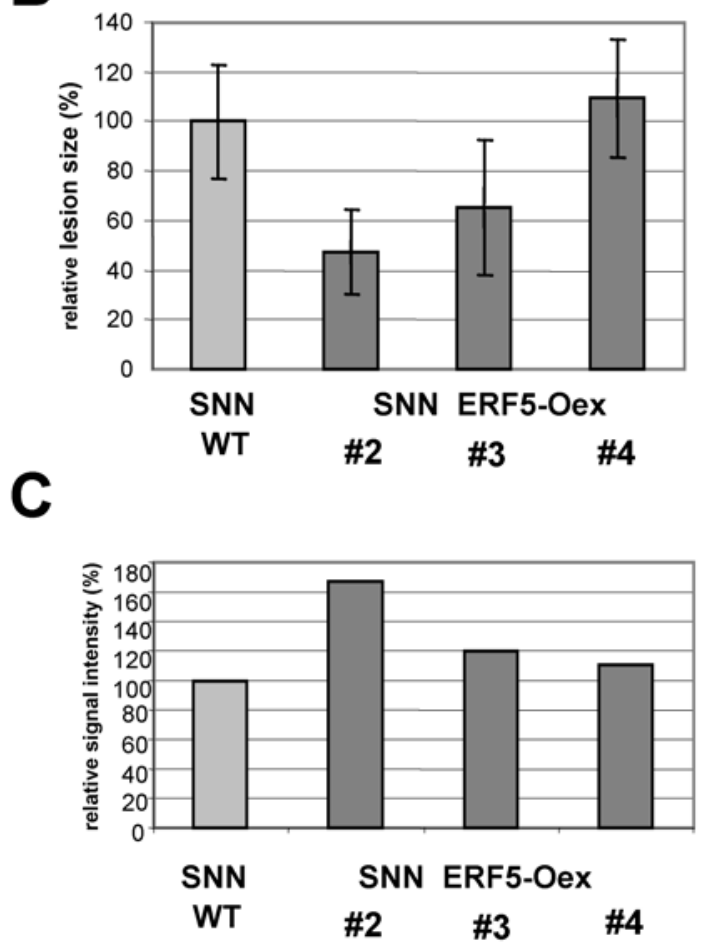

Fig. 5. Tobacco mosaic virus (TMV) resistance of Samsum (NN) plants overexpressing NtERF5. A, Comparison of TMV-induced hypersensitive response (HR) lesions obtained after infection of tobacco wild-type (WT) and SNN-ERF5-Oex plants. B, Quantitative measurements of the diameter of HR lesions. Mean values of 50 lesions in relation to the wildtype lesion size (defined as $100 \%$ ) are given. C, Northern analysis of NtERF5 overexpressing plants that have been analyzed in B. Quantified levels of steady state NtERF5 transcription in relation to the wild-type expression (defined as $100 \%$ ) are given. Numbers indicate independent transformants.
In comparison with TMV-infected wild-type SNN plants, ERF5-Oex plants display lesions of reduced size (Fig. 5A and $B)$. The reduction of lesion size corresponds to the level of NtERF5 steady-state transcripts as monitored by Northern analysis (Fig. 5C).

Resistance to TMV might be due either to reduced viral spread, replication, or both. To further assess the mechanism of ERF5-mediated TMV resistance, a temperature shift experiment was performed. Plants cultivated at $32^{\circ} \mathrm{C}$ were infected with TMV. After 4 days, temperature was shifted to $22^{\circ} \mathrm{C}$ (Fig. $6 \mathrm{~A}$ ), which initiates a massive $N$ gene-mediated plant defense response. Directly infected leaves (local infected leaves) of wild-type and ERF5-Oex plants collapse within several hours after temperature shift (data not shown). During four days of culture at $32^{\circ} \mathrm{C}$, the virus has spread systemically, and after shifting temperature, systemically infected leaves at the apex of wild-type plants collapse as well. Surprisingly, systemically infected leaves of ERF5-Oex plants showed no sign of cell death, indicating that the virus had not entered this tissue (Fig. $6 \mathrm{~B})$. Since the $N$ gene-mediated resistance is inactivated at high temperature, the observed resistance is due to an $N$ geneindependent mechanism.

To examine this phenomenon on the molecular level, we analyzed TMV-induced PRIa expression in directly and systemically infected leaves at the RNA and protein levels. Whereas, no difference in PRIa expression was observed in the directly infected leaves of wild-type and ERF5-Oex plants, PRla steady-state RNA and protein accumulation was reduced in systemically infected leaves of ERF5-Oex plants (Fig. 6C). Accordingly, as monitored by ethidium bromide staining of viral RNA, TMV was observed in systemically infected leaves of wild-type plants but not in ERF5-Oex plants. These data suggest that the amount of TMV or systemic movement of the virus, or both, is reduced in ERF5-Oex plants. In agreement with this notion, the local response of several defense or $P R$ genes in ERF5-Oex plants was comparable to wild type, but no induction of these genes was observed in systemically infected ERF5-Oex leaves (Fig. 6D). Overexpression of several $E R F$ genes in transgenic plants resulted in constitutive expression of $P R$ and defense genes. In contrast, no constitutive activation of $P R$ (e.g., $P R l a, P R l b, P R 3$ ) or defense-related genes (e.g., SAR8.2, HMGR, PAL) was observed in ERF5-Oex plants (Fig. 6D). Moreover, the kinetics of pathogen-induced transcription in directly infected leaves were comparable in ERF5Oex and wild-type plants.

To analyze the mechanism that leads to TMV resistance in ERF5-Oex plants, we measured the steady-state TMV-RNA level in locally infected leaves. Immediately after temperature shift $(0 \mathrm{~h})$ and after 8 and $24 \mathrm{~h}$, respectively, TMV-specific RNA was quantified (Fig. 7). In comparison with wild-type plants, we detected only 10 to $30 \%$ of TMV-RNA in the infected ERF5-Oex leaves. Since TMV-RNA levels have been measured at $32^{\circ} \mathrm{C}$, these data indicate that the $N$ gene-mediated defense is not involved in reducing viral RNA. In conclusion, overexpression of NtERF5 is sufficient to enhance resistance to $\mathrm{TMV}$, most likely by regulating viral propagation.

\section{DISCUSSION}

In this study we have identified NtERF5, a new member of the tobacco AP2/ERF transcription factor family that enhances plant resistance to TMV when overexpressed. Overexpression of ERF genes has been shown to result in resistance to bacterial and fungal pathogens (Berrocal-Lobo et al. 2002; Gu et al. 2002; He et al. 2001). Here, we further extend strategies to engineer plants displaying an enhanced resistance to viral attack by overexpressing NtERF5. 
Tobacco ERFs have been shown to act as activators or repressors of transcription. Whereas NtERF3 is characterized by the well-defined EAR repressor domain (Hiratsu et al. 2003; Ohta et al. 2001), $N t \mathrm{ERF} 1, N t \mathrm{ERF} 2$, and $N t \mathrm{ERF} 4$, as well as Tsi1 have been shown to function as transcriptional activators in plant cells or yeast, respectively (Ohta et al. 2000; Park et al. 2001). Stretches of acidic amino acids are located at the $\mathrm{N}$ and $\mathrm{C}$ termini of $N t$ ERF5, which have been shown to possess acti- vation properties (Lemon and Tjian 2000). Hence, NtERF5 might act as a transcriptional activator in planta.

Whereas the NtERF5 DNA-binding domain is highly conserved, other parts of the protein differ considerably from other described tobacco ERFs, like $N t \mathrm{ERF} 1$ to $N t \mathrm{ERF} 4$ or Tsi 1 (Fig. 1). The most related protein is ERF1 from A. thaliana (Solano et al. 1998). In particular, NtERF5 and ERF1 share acidic domains in the $\mathrm{N}$ and $\mathrm{C}$ termini. However, since only a
A

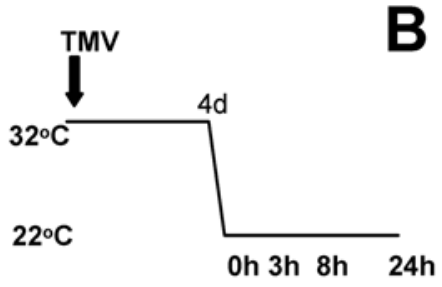

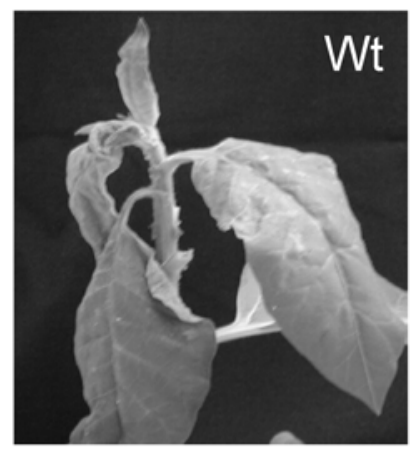

C

\begin{tabular}{|c|c|c|c|}
\hline \multicolumn{4}{|c|}{\begin{tabular}{ll}
\multicolumn{2}{c}{ SNN WT } \\
local infection & systemic
\end{tabular}} \\
\hline mock & TMV & mock & TMV \\
\hline $\begin{array}{llll}0 & 3 & 8 & 24\end{array}$ & $\begin{array}{llll}0 & 3 & 824\end{array}$ & $\begin{array}{llll}0 & 3 & 8 & 24\end{array}$ & $\begin{array}{llll}0 & 3 & 8 & 24\end{array}$ \\
\hline
\end{tabular}

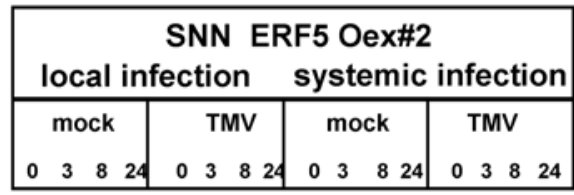

$t(h)$

a
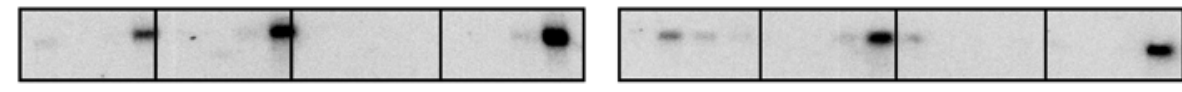

PR1a

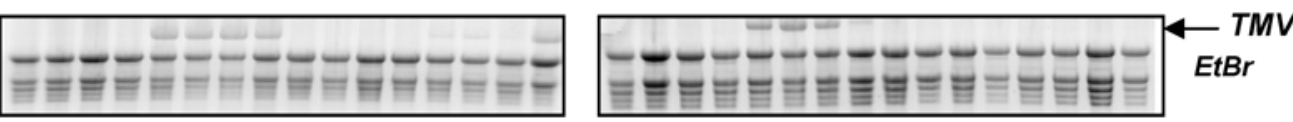

b

\begin{tabular}{|l|lllllllllllllll|l|}
\hline 0 & 24 & 0 & 24 & 0 & 24 & 0 & 24 & 0 & 24 & 0 & 24 & 0 & 24 & 0 & 24 & $\mathrm{t}(\mathrm{h})$ \\
\hline & & & & & & & & & & - & & & & \\
PR1a
\end{tabular}

D
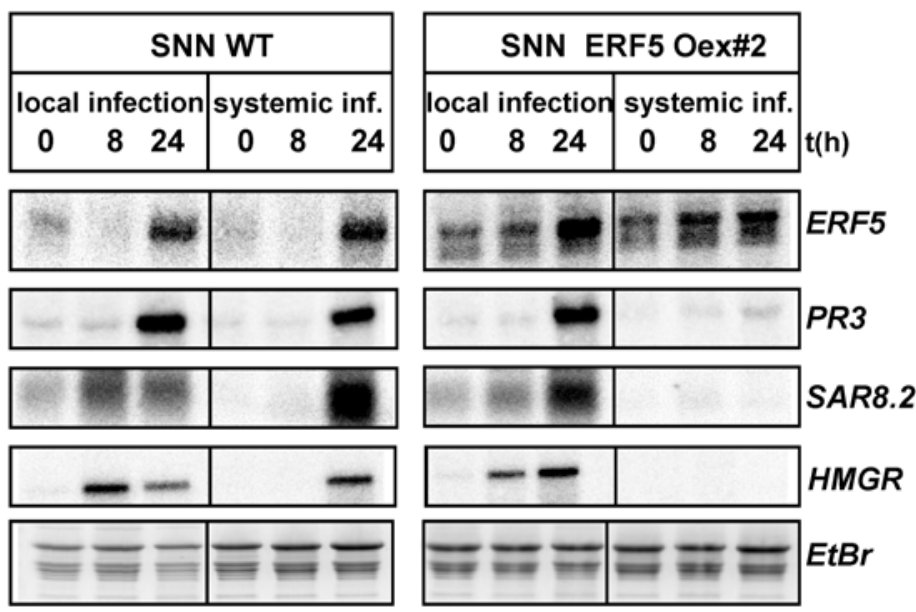

Fig. 6. Analysis of the systemic spread of Tobacco mosaic virus (TMV) in wild-type and NtERF5 overexpressing Samsum (NN) plants (SNN-ERF5-Oex). A, Experimental design: tobacco plants were infected at $32^{\circ} \mathrm{C}$. After 4 days, temperature was shifted to $22^{\circ} \mathrm{C}$. Directly infected tissues as well as systemically infected tissues (at the plant apex) were harvested at the timepoints indicated. B, Defense responses of apical leaves of wild-type (left) and SNNERF5-Oex plants (right) that have been infected with TMV on basal leaves. The plants are shown four days after temperature shift. C, PRla expression in directly (local) and systemically infected leaves. Mock- and TMV-infiltrated tissue was harvested at the timepoints indicated and were analyzed for PRIa transcripts (a, Northern blot) or PR1a protein (b, Western blot), respectively. Loading of the RNA gel and TMV RNA (arrow) was monitored by ethidium bromide staining $(\mathrm{EtBr})$. D, Expression of several pathogenesis related $(P R)$ and defense genes in wild-type and SNN-ERF5-Oex plants. RNA preparations on directly infected basal leaves and systemically infected apical leaves are analyzed. PR3 (Lawton et al. 1992), SAR8.2 (Herbers et al. 1996), and HMGR (Kang et al. 1998). 
limited number of the tobacco $E R F$ family members have been isolated, $N t$ ERF5 orthologs are difficult to assign.

As far as functions are described, members of the AP2 subfamily are involved in developmental aspects (Riechmann and Meyerowitz 1998), whereas ERFs mediate plant stress responses. Developmental or tissue-specific expression of $N t E R F 5$ has been detected only in sepals of the tobacco flower, indicating a possible function during flower development. $P R$ genes have been shown to be ERF targets (Chakravarthy et al. 2003; Ohme-Takagi and Shinshi 1995; Ohta et al. 2000), and expression of $P R I b$ and $P R 2$ has been detected in parts of the flower (Cote et al. 1991). Whether PR proteins have specific functions during flower development or whether they defend flowers and developing seeds against pathogens is not wellinvestigated. Since NtERF5 overexpression does not lead to changes in vegetative or generative plant growth, there is no indication that $\mathrm{NtERF5}$ plays a role in plant development.

$N t E R F 5$ transcription is strongly enhanced by infection with the bacterial pathogen $P$. syringae. In comparison with the compatible interaction, NtERF5 transcription is enhanced with an accelerated kinetic during incompatible interaction, indicating that the transcriptional response is triggered by a specific pathogen-derived avirulence factor. NtERF5 transcription is also induced by TMV. These data imply that NtERF5 plays a more general role in plant pathogen defense. Abiotic stresses like cold and salt treatment do not induce NtERF5 transcription (U. Fischer and W. Dröger-Laser, unpublished data). As has been described for NtERF2, NtERF3, and NtERF4 (Nishiuchi et al. 2002), NtERF5 transcription is transiently induced by various wound treatments, which might also be related to a function in pathogen defense.

Two well-defined signaling pathways are involved in pathogen-defense responses that make use of the plant hormones SA or ethylene/JA, respectively (Dong 2001). Whereas ERF1 from Arabidopsis is induced by ethylene or JA, transcription of NtERF5 and Pti5 are not enhanced by any of these hormones (Gu et al. 2000; Thara et al. 1999). These data suggest that these proteins, although closely related, have divergent functions. Moreover, our results suggest that pathogeninduced NtERF5 transcription is either mediated independently of the SA or ethylene/JA pathways or single hormone action is not sufficient to trigger the response.

Overexpression of several ERF genes has been shown to result in tolerance to abiotic (Stockinger et al. 1997; Liu et al. 1998) or biotic (Park et al. 2001) stresses. Analysis of several $P R$ promoters reveals GCC cis-elements to be crucial for pathogen-induced gene activation. However, different ERF proteins

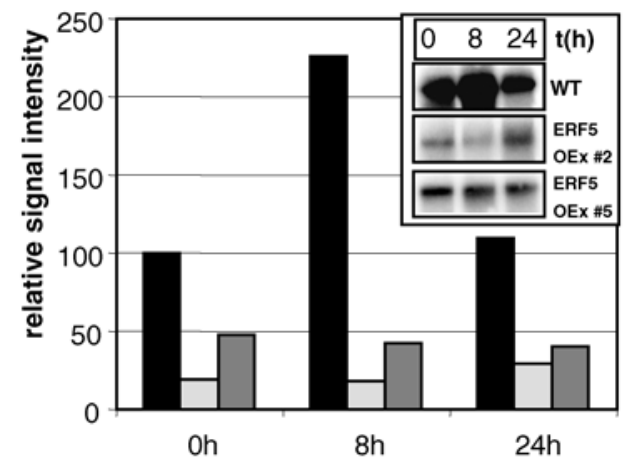

Fig. 7. Propagation of Tobacco mosaic virus (TMV) in leaves of directly infected wild-type (black) and SNN ERF5-Oex \#2 (dark gray) and SNN ERF5-Oex \#5 (light gray) plants. Steady-state TMV-RNA was quantified $0 \mathrm{~h}, 8 \mathrm{~h}$, and $24 \mathrm{~h}$ after temperature shift and were calculated in relation to TMV-RNA accumulation in wild-type plants at the $0 \mathrm{~h}$ timepoint (defined as $100 \%$ ). induce only a subset of $P R$ genes. For example, overexpression of Arabidopsis ERF1 results in constitutive activation of $\beta$-Glu, $b$-CHI, or PDF1.2, whereas expression of tomato Pti4 in Arabidopsis leads to activation of $P R 1, P R 3$ (chitinase), PR4, and $P D F 1.2$, which are typical markers for the SA or the ethylene/JA pathway ( $\mathrm{Gu}$ et al. 2002; Lorenzo et al. 2003). Only slight induction of $P R I$ was observed by Pti5 overexpressing plants. In tomato, Pti5 expression causes no constitutive gene activation but potentiates pathogen-induced activation of $\beta$-glucanase and catalase genes (He et al. 2001). ERF5-Oex plants show no constitutive $P R$ gene expression. Furthermore, $N t$ ERF5 does not potentiate pathogen-induced $P R$ gene expression, as has been shown for Pti5-overexpressing plants. In conclusion, these data support the view that the huge number of $E R F$ genes reflects not redundant but distinct functions of the plant to deal with specific environmental stress conditions.

The amino acids of the ERF DNA-binding domain that are crucial for in vitro binding to GCC or DREB boxes have been defined (Hao et al. 1998, 2002, 2003; Sakuma et al., 2002). According to these data, NtERF5 harbors typical amino acids (A14, D19) that should mediate a GCC box-specific binding activity. Although NtERF5 was isolated by binding to GC-rich sequences in a yeast one-hybrid screen, recombinant HIStagged $N t$ ERF5 protein only weakly interacted with GCC box-containing promoter fragments in vitro. Moreover, no in vitro binding to DREB elements was observed. In contrast, $A t$ ERF1 recombinant protein used as a control efficiently binds GCC boxes under identical conditions. In the case of the barley ERF protein $H v C B F 2$, in vitro binding was enhanced by low temperature (Xue 2003). However several attempts varying conditions of incubation, binding buffers, and protein preparation failed to enhance in vitro DNA binding. Moreover, since $N t$ ERF5 can activate transcription mediated by GC-rich cis elements in yeast, we propose that additional cofactors or posttranslational modifications are necessary for efficient binding to GCC boxes. As has been shown by $\mathrm{Gu}$ and associates (2000), phosphorylation of Pti4 by the serine-threonine kinase Pto enhances its DNA binding in vitro. Anticipating that GCC boxes are target sites of NtERF5, a posttranslational mechanism to regulate DNA binding of $N t$ ERF5 in vivo has to be postulated. In a recent study, in vivo binding of the ERF protein Pti4 was shown by means of chromatin immuno precipitation even to promoters harboring no GCC box (Chakravarthy et al. 2003). Hence, we cannot exclude the possibility that other unknown promoter cis elements might be targeted by ERFs. Furthermore, protein-protein interaction has been shown between $A t$ EBP and a member of the TGA class of bZIP transcription factors (Buttner and Singh 1997). In many $P R$ promoters, GCC boxes are clustered with $\mathrm{W}$ boxes or $a s-1$ elements, which are supposed to be regulated by WRKY or TGA transcription factors, respectively (Maleck et al. 2000). Hence, it is tempting to speculate that a synergistic action of these transcription factors might affect DNA binding and selection of the subset of $P R$ promoters that are regulated by a specific ERF. These data support the view, that the presence of a GCC box itself is not sufficient for ERF-mediated gene activation. Chromatin immuno precipitation will provide further insight into ERF5 in vivo binding sites.

In contrast to Tsi1, which when overexpressed, leads to broad spectrum resistance (Shin et al. 2002), NtERF5 overexpression specifically resulted in enhanced resistance to TMV. Resistance is due to a significantly reduced accumulation of TMV-RNA in infected leaves, implying that $N t$ ERF5-regulated genes are involved in suppressing viral replication. Since viral RNA accumulation is reduced also at $32^{\circ} \mathrm{C}$, this resistance is not due to an $N$ gene-mediated mechanism. The reduced lesion size might also be a result of an inhibition of viral move- 
ment. Therefore, infected plants were incubated at $32^{\circ} \mathrm{C}$, to allow systemic spread of the virus. In comparison to wild-type plants, no TMV-RNA, TMV-induced HR, or defense gene activation was observed in the upper part of the plants. These data indicate that viral spread is strongly suppressed in ERF5-Oex plants. However, we cannot rule out that the suppression of viral spread is a consequence of the reduced TMV propagation in the primary infected leaves. Thus, the mechanism of exactly how NtERF5 is mounting a plant defense to TMV remains elusive. Treatment with SA (Murphy and Carr 2002) as well as the presence of several host factors have been implicated in resistance to TMV replication and viral spread (Abbink et al. 2002; Akad et al. 1999; Valentine et al. 2002). It must be noted that the observed resistance phenotype is based on overexpression studies, and in order to demonstrate whether ERF5 is part of a natural-occurring resistance pathway, RNAi plants will need to be analyzed. Furthermore, the use of gene array analysis will assist in defining $N t$ ERF5 target genes, to further elucidate the mechanism of how NtERF5 is mounting a resistant response to viral infection.

\section{MATERIALS AND METHODS}

\section{Plant material, plant cultivation, plant infection.}

Tobacco cultivars Samsun (NN) and Wisconsin W38 (nn) were grown in a growth chamber under a 16-h-light and 8-hdark regime at $22^{\circ} \mathrm{C}$ and $85 \%$ humidity. For TMV infection, fully expanded leaves of 6- to 8-week-old, soil-grown tobacco plants were used. Inoculation with TMV strain U1 (5 mg per leaf) was performed in $50 \mathrm{mM}$ potassium phosphate buffer, $\mathrm{pH}$ 7.5 , by gently rubbing the leaves with Carborundum, using a method which has been described previously (Yalpani et al. 2001). Mock treatment was done with Carborundum and buffer. HR was induced by incubating TMV-inoculated plants at $32^{\circ} \mathrm{C}$ for 4 days and then shifting temperature to $22^{\circ} \mathrm{C}$, as has been described previously (Malamy et al. 1992). For bacterial infection, leaves from 6-week-old tobacco plants were infiltrated with a $P$. syringae pv. pisi (Cournoyer et al. 1995) or P. syringae pv. tabaci (Salch and Shaw 1988) suspension $(1 \times$ $\left.10^{5} \mathrm{CFU} / \mathrm{ml}\right)$. Infection inoculum was calculated to be 500 CFU per infection. For each timepoint, bacteria from 20 independent infection sites were harvested from two to three independent plants and were titered by plating on King's B medium (King et al. 1954). With respect to Northern blot experiments, leaves were inoculated with $100 \mu \mathrm{l}$ of a bacterial suspension $\left(10^{7} \mathrm{CFU} / \mathrm{ml}\right)$.

For application of signal molecules, leaves from 6-week-old tobacco plants were sprayed with a solution containing $1 \mathrm{mM}$ ethephon (Sigma, Taufkirchen, Germany) in $50 \mathrm{mM}$ sodium phosphate buffer ( $\mathrm{pH} 7.0$ ) or $0.1 \mathrm{mM} \mathrm{JA}$ in water. Leaf disks were floated on $50 \mathrm{mM}$ sodium phosphate buffer $(\mathrm{pH} 5.8)$ with $1 \mathrm{mM}$ SA.

\section{Standard molecular biological techniques.}

Standard DNA techniques were used according to Sambrook and associates (1989). DNA sequence analysis was performed on an ABI310 sequencer, using an ABI PRISM BigDye terminator cycle sequencing reaction kit. RACE has been performed using a SMART-RACE cDNA amplification kit (Clontech, Palo Alto, CA, U.S.A.).

\section{Yeast one-hybrid screening.}

The commercial "matchmaker" yeast one-hybrid system (Clontech) was used according to the manufacturer's protocol. Yeast one-hybrid vectors are based on pHISi-1 and pLacZi coding for HIS3 and lacZ reporter gene, respectively (Clontech). Various cis elements have been used for the yeast one- hybrid screening. For example, oligonucleotides carrying a $\mathrm{C}$ box (5'TAGATACAATTGACGTCATGTATCAT 3', 3'CTATG TTAACTGCAGTACATAGTAAT $5^{\prime}$ ) were annealed, multimerized, and inserted into the NdeI site of pUK21. As a control $\mathrm{K}$ box, oligonucleotides were used harboring specific mutations in the cis element (5'TAGATACAATTaAgtaaATGT ATCAT 3', 3'CTATGTTAAtTcattTACATAGTAAT 5'). Fragments carrying four copies of the $\mathrm{C}$ box and $\mathrm{K}$ box were obtained by $E c o$ RI and $X b a \mathrm{I}$ restriction and were inserted into pHISi-1. Due to this cloning step, a GC-rich sequence (TGG ATC CGA TAT CGC CGT GGC GGC CGC TCT AGA) from the mcs of pUK21 has been included into the pHIS-1 screening vector. The HIS reporter genes were integrated into the yeast chromosomal background, using the procedure described in the manufacturer's protocol. For yeast one-hybrid screening, a tobacco SR1 cDNA library (Strathmann et al. 2001) has been constructed in pGAD424 (Clontech). Yeast transformants were selected on medium lacking histidine and were supplemented with $45 \mathrm{mM}$ 3-AT (3-aminotriazol). The vector pGAD-ERF5, which encodes an activation domain NtERF5 fusion, activates the HIS reporter genes independently of whether they are driven by the $\mathrm{C}$ or $\mathrm{K}$ box cis elements. To test whether ERF5 binds to the artificial GC-rich sequence, which has been included in the screening construct due the cloning strategy, C- and K-box-containing EcoRI-EcoRV fragments were inserted into the vector pLacZi. The vectors obtained do not harbor the GC-rich sequence, and expression of GADERF5 does not result in lacZ reporter gene activation. We therefore conclude that ERF5 binds the GC-rich sequence and none of the specifically introduced cis elements. $\beta$-Galactosidase assays were performed as described in Strathmann and associates (2001).

\section{Plant transformation.}

The NtERF5 cDNA was inserted into the EcoRI site of pBluescriptIISK (Stratagene, La Jolla, Ca, U.S.A.). After restriction with $A c c \mathrm{I}$ and XbaI, NtERF5 was obtained from pBluescriptIISK and inserted into the plant transformation vector pBINHygTx (Rieping et al. 1994). Agrobacterium-mediated transformation of the Nicotiana tabacum cultivars Samsun $(\mathrm{NN})$ and Wisconsin W38 (nn) was performed as previously described (Strathmann et al. 2001).

\section{Protein techniques.}

Recombinant $N t$ ERF5 protein was prepared by inserting an EcoRI fragment obtained from pGAD-ERF5 into the HIS-tag vector pET28a (Novagene, Abingdon, U.K.). AtERF1 was PCR-amplified using the primers 5' GGG GAC AAG TTT GTA CAA AAA AGC AGG CTT CAT GAC GGC GGA TTC TCA ATC TG 3' and GGG GAC CAC TTT GTA CAA GAA AGC TGG GTT TAT AAA ACC AAT AAA CGA TCG 3'. The fragment was inserted into the GATEWAY vector pDONR201 (Invitrogen, Karlsruhe, Germany). Via recombination, AtERF1 was integrated into the HIS-tag vector pDEST17 (Invitrogen). Expression studies were performed in $E$. coli $\mathrm{B} 121$ (Stratagene, La Jolla, CA, U.S.A.). After induction with $1 \mathrm{mM}$ isopropyl- $\beta$-D-thiogalactoside, recombinant proteins were purified, using the Ni-NTA resin according to the manufacturer's protocol (Qiagen, Hildesheim, Germany).

Proteins were separated using a $10 \%$ sodium dodecyl sulfate-polyacrylamide gel electrophoresis (Sambrook et al. 1989) and were transferred to a polyvinylidene diflouride membrane (Millipore, Braunschweig, Germany), following the procedure described previously (Strathmann et al. 2001). For immuno-detection, a HIS-tag-specific antibody (M. Benley, Göttingen, Germany), a PR-specific monoclonal antibody (D. Klessig, Boyce Thompson Institute, Ithaca, NY, U.S.A.), and 
an anti-rabbit immunoglobin horseradish peroxidase-linked antibody from donkey (Amersham Bioscience, Freiburg, Germany) were applied. Visualization was performed using the ECL+ system (Amersham-Bucher, Braunschweig, Germany).

\section{EMSA.}

EMSA has been performed as described by Lyss and associates (1998). The following oligonucleotides were used for the binding reactions:

GCC box (Fujimoto et al. 2000):

5' ATG AGT TAA CGC AGA CAT AGC CGC CAT TT 3' 5' TAC TCA ATT GCG TCT GTA TCG GCG GTA AA 3' GCCmut box:

5' ATG AGT TAA CGC AGA CAT AtC CtC CAT TT 3' 5' TAC TCA ATT GCG TCT GTA TaG GaG GTA AA 3' DREB box (Sakuma et al. 2002):

5' ATG AGT TAA GCG AGA CAT ATA CCG ACA TAT TT 3' 5' TAC TCA ATT GCG TCT GTA TAT GGC TGT ATA AA 3' GC rich (pUK21):

5' TGG ATC CGA TAT CGC CGT GGC GGC CGC TCT AGA $3^{\prime}$

5' ACC TAG GCT ATA GCG GCA CCG CCG GCG AGA TCT $3^{\prime}$

\section{Northern blot analysis.}

Total RNA was purified from tobacco tissue by using the RNeasy plant mini kit (Qiagen). Northern hybridization was performed as described in Strathmann and associates (2001). The following hybridization probes have been used: a 1,000bp EcoRI fragment from NtERF5, a 531-bp EcoRI/BamHI fragment from PRla (Cutt et al. 1988), a 1,000-bp PstI fragment from PR3 (Lawton et al. 1992), an 800-bp SalI/BamHI fragment from the movement protein of TMV (D. Hofius, unpublished data), a 440-bp PCR fragment coding for ACC oxidase (Kim et al. 1998), a 1,000-bp EcoRI fragment from HMGR (Kang et al. 1998), and a 1,000-bp EcoRI fragment from SAR 8.2 (Herbers et al. 1996). Quantification of hybridization signals was achieved by using Bio-imager analysis (BAS-1000, Fuji, Tokyo) and Tina software (Raytest, Straubenhardt, Germany).

\section{ACKNOWLEDGMENTS}

We thank C. Gatz and R. Weigel for critically reading the manuscript and D. Hofius (IPK, Gatersleben, Germany), M. Ohme-Takagi (Japan), D. Klessig (Boyce Thompson Institute, Ithaca, NY, U.S.A.) and M. Benley (Biosystems, Göttingen, Germany) for providing DNA constructs and antibodies, respectively.

\section{LITERATURE CITED}

Abbink, T. E., Peart, J. R., Mos, T. N., Baulcombe, D. C., Bol, J. F., and Linthorst, H. J. 2002. Silencing of a gene encoding a protein component of the oxygen-evolving complex of photosystem II enhances virus replication in plants. Virology 295:307-319.

Akad, F., Teverovsky, E., David, A., Czosnek, H., Gidoni, D., Gera, A. and Loebenstein, G. 1999. A cDNA from tobacco codes for an inhibitor of virus replication (IVR)-like protein. Plant Mol. Biol. 40:969-976.

Allen, M. D., Yamasaki, K., Ohme-Takagi, M., Tateno, M., and Suzuki, M. 1998. A novel mode of DNA recognition by a beta-sheet revealed by the solution structure of the GCC-box binding domain in complex with DNA. EMBO (Eur. Mol. Biol. Organ.) J. 17:5484-5496.

Berrocal-Lobo, M., Molina, A., and Solano, R. 2002. Constitutive expression of ETHYLENE-RESPONSE-FACTOR1 in Arabidopsis confers resistance to several necrotrophic fungi. Plant J. 29:23-32.

Buttner, M., and Singh, K. B. 1997. Arabidopsis thaliana ethylene-responsive element binding protein (AtEBP), an ethylene-inducible, GCC box DNA-binding protein interacts with an ocs element binding protein. Proc. Natl. Acad. Sci. U.S.A. 94:5961-5966.

Chakravarthy, S., Tuori, R. P., D’Ascenzo, M. D., Fobert, P. R., Despres, C., and Martin, G. B. 2003. The tomato transcription factor Pti4 regu- lates defense-related gene expression via GCC box and non-GCC box cis elements. Plant Cell 15:3033-3050.

Cote, F., Cutt, J. R., Asselin, A., and Klessig, D. F. 1991. Pathogenesisrelated acidic $\beta$-1,3-glucanase genes of tobacco are regulated by both stress and developmental signals. Mol. Plant-Microbe Interact. 4:173181.

Cournoyer, B., Sharp, J. D., Astuto, A., Gibbon, M. J., Taylor, J. D., and Vivian, A. 1995. Molecular characterization of the Pseudomonas syringae pv. pisi plasmid-borne avirulence gene avrPpiB which matches the $R 3$ resistance locus in pea. Mol. Plant-Microbe Interact. 8:700-708.

Cutt, J. R., Dixon, D. C., Carr, J. P., and Klessig, D.F. 1988. Isolation and nucleotide sequence of cDNA clones for the pathogenesis-related proteins PR1a, PR1b and PR1c of Nicotiana tabacum cv. Xanthi nc induced by TMV infection. Nucleic Acids Res. 16:9861.

Daniel, X., Lacomme, C., Morel, J. B., and Roby, D. 1999. A novel $m y b$ oncogene homologue in Arabidopsis thaliana related to hypersensitive cell death. Plant J. 20:57-66.

Dong, X. 2001. Genetic dissection of systemic acquired resistance. Curr. Opin. Plant Biol. 4:309-314.

Dubouzet, J. G., Sakuma, Y., Ito, Y., Kasuga, M., Dubouzet, E. G., Miura, S., Seki, M., Shinozaki, K., and Yamaguchi-Shinozaki, K. 2003. OsDREB genes in rice, Oryza sativa L., encode transcription activators that function in drought-, high-salt- and cold-responsive gene expression. Plant J. 33:751-763.

Eulgem, T., Rushton, P. J., Robatzek, S., and Somssich, I. E. 2000. The WRKY superfamily of plant transcription factors. Trends Plant Sci. 5:199-206.

Fujimoto, S. Y., Ohta, M., Usui, A., Shinshi, H., and Ohme-Takagi. M. 2000. Arabidopsis ethylene-responsive element binding factors act as transcriptional activators or repressors of GCC box-mediated gene expression. Plant Cell 12:393-404

Gu, Y. Q., Yang, C., Thara, V. K., Zhou, J., and Martin, G. B. 2000. Pti4 is induced by ethylene and salicylic acid, and its product is phosphorylated by the Pto kinase. Plant Cell 12:771-786.

Gu, Y. Q., Wildermuth, M. C., Chakravarthy, S., Loh, Y. T., Yang, C., He, X., Han, Y., and Martin, G.B. 2002. Tomato transcription factors Pti4, Pti5, and Pti6 activate defense responses when expressed in Arabidopsis. Plant Cell 14:817-831.

Hao, D., Ohme-Takagi, M., and Sarai, A. 1998. Unique mode of GCC box recognition by the DNA-binding domain of ethylene-responsive elementbinding factor (ERF domain) in plant. J. Biol. Chem. 273:26857-26861.

Hao, D., Yamasaki, K., Sarai, A., and Ohme-Takagi, M. 2002. Determinants in the sequence specific binding of two plant transcription factors, CBF1 and NtERF2, to the DRE and GCC motifs. Biochemistry 41:4202-4208.

Hao, D., Ohme-Takagi, M., and Yamasaki, K. 2003. A modified sensor chip for surface plasmon resonance enables a rapid determination of sequence specificity of DNA-binding proteins. FEBS (Fed. Eur. Biochem. Soc.) Lett. 536:151-156.

He, P., Warren, R. F., Zhao, T., Shan, L., Zhu, L., Tang, X., and Zhou, J.M. 2001. Overexpression of Pti5 in tomato potentiates pathogeninduced defense gene expression and enhances disease resistance to Pseudomonas syringae pv. tomato. Mol. Plant-Microbe Interact. 14:1453-1457.

Herbers, K., Meuwly, P., Metraux, J. P., and Sonnewald, U. 1996. Salicylic acid-independent induction of pathogenesis-related protein transcripts by sugars is dependent on leaf developmental stage. FEBS (Fed. Eur. Biochem. Soc.) Lett. 397:239-244.

Hiratsu, K., Matsui, K., Koyama, T., and Ohme-Takagi, M. 2003. Dominant repression of target genes by chimeric repressors that include the EAR motif, a repression domain, in Arabidopsis. Plant J. 34:733-739.

Jakoby, M., Weisshaar, B., Dröge-Laser, W., Tiedemann, J., Kroij, T., and Parcy, F. 2002. The family of bZIP transcription factors in Arabidopsis thaliana. Trends Plant Sci. 7:106-111.

Kagaya, Y., Ohmiya, K., and Hattori, T. 1999. RAV1, a novel DNA-binding protein, binds to bipartite recognition sequence through two distinct DNA-binding domains uniquely found in higher plants. Nucleic Acids Res. 27:470-478

Kang, M. K., Park, K. S., and Choi, D. 1998. Coordinated expression of defense-related genes by TMV infection or salicylic acid treatment in tobacco. Mol. Cells 8:388-392.

Kim, Y. S., Choi, D., Lee, M. M., Lee, S. H., and Kim, W. T. 1998. Biotic and abiotic stress-related expression of 1-aminocyclopropane-1-carboxylate oxidase gene family in Nicotiana glutinosa L. Plant Cell Physiol. 39:565-573.

King, E. O., Ward, M. K., and Raney, D. E. 1954. Two simple media for the demonstration of phycocyanin and fluorescin. J. Lab. Clin. Med 44:301-307.

King, G. A., O’Donoghue, E. M., Borst, W.M., Davies, K. M., Moyle, R L., and Farnden, K. J. 1996. Identification and characterization of an 
mRNA encoding a proline-rich protein that rapidly declines in abundance in the tips of harvested asparagus spears. Plant Cell. Physiol. 37:706-710

Kizis, D., Lumbreras, V., and Pages, M. 2001. Role of AP2/EREBP transcription factors in gene regulation during abiotic stress. FEBS (Fed. Eur. Biochem. Soc.) Lett. 498:187-189.

Klessig, D. F., Durner, J., Noad, R., Navarre, D. A., Wendehenne, D., Kumar, D., Zhou, J. M., Shah, J., Zhang, S., Kachroo, P., Trifa, Y., Pontier, D., Lam, E., and Silva, H. 2000. Nitric oxide and salicylic acid signaling in plant defense. Proc. Natl. Acad. Sci. U.S.A.97:8849-8855.

Lawton, K., Ward, E., Payne, G., Moyer, M., and Ryals, J. 1992. Acidic and basic class III chitinase mRNA accumulation in response to TMV infection of tobacco. Plant Mol. Biol. 19:735-743.

Lemon, B., and Tjian, R. 2000. Orchestrated response: A symphony of transcription factors for gene control. Genes Dev. 14:2551-2569.

Liu, Q., Kasuga, M., Sakuma, Y., Abe, H., Miura, S., YamaguchiShinozaki, K., Shinozaki, K. 1998. Two transcription factors, DREB1 and DREB2, with an EREBP/AP2 DNA binding domain separate two cellular signal transduction pathways in drought- and low-temperatureresponsive gene expression, respectively, in Arabidopsis. Plant Cell 10:1391-1406.

Lorenzo, O., Piqueras, R., Sanchez-Serrano, J. J., and Solano, R. 2003. ETHYLENE RESPONSE FACTOR1 integrates signals from ethylene and jasmonate pathways in plant defense. Plant Cell 15:165-178.

Lyss, G., Knorre, A., Schmidt, T. J., Pahl, H. L., Merfort, I. 1998. The anti-inflammatory sesquiterpene lactone helenalin inhibits the transription factor NR-(kappa)B by directly targeting p65. J. Biol. Chem. 273:33508-33516.

Malamy, J., Hennig, J., and Klessig D. F. 1992. Temperature induction of salicylic acid and its conjugates during response to tobacco mosaic virus infection. Plant Cell 4:359-365.

Maleck, K., Levine, A., Eulgem, T., Morgan, A., Schmid, J., Lawton, K. A., Dangl, J. L., and Dietrich, R. A. 2000. The transcriptome of Arabidopsis thaliana during systemic acquired resistance. Nature Genet. 26:403-410.

Murphy, A. M., Carr, J. P. 2002. Salicylic acid has cell-specific effects on tobacco mosaic virus replication and cell-to-cell movement. Plant Physiol. 128:552-563.

Nishiuchi, T., Suzuki, K., Kitajima, S., Sato, F., and Shinshi, H. 2002. Wounding activates immediate early transcription of genes for ERFs in tobacco plants. Plant Mol. Biol. 49:473-482.

Ohme-Takagi, M., and Shinshim, H. 1995. Ethylene-inducible DNA binding proteins that interact with an ethylene-responsive element. Plant Cell 7:173-182.

Ohme-Takagi, M., Suzuki, K., and Shinshi, H. 2000. Regulation of ethylene-induced transcription of defense genes. Plant Cell Physiol. 41:1187-1192.

Ohta, M., Matsui. K., Hiratsu, K., Shinshi, H., and Ohme-Takagi, M. 2001. Repression domains of class II ERF transcriptional repressors share an essential motif for active repression. Plant Cell 13:1959-1968.

Ohta, M., Ohme-Takagi, M., and Shinshi. H. 2000. Three ethylene-responsive transcription factors in tobacco with distinct transactivation functions. Plant J. 22:29-38.

Okamuro, J. K., Caster, B., Villarroel, R., Van-Montagu, M., and Jofuku, K. D. 1997. The AP2 domain of APETALA2 defines a large new family of DNA binding proteins in Arabidopsis. Proc. Natl. Acad. Sci. U.S.A. 94:7076-7081.

Park, J. M., Park, C. J., Lee, S. B., Ham, B. K., Shin, R., and Paek, K. H. 2001. Overexpression of the tobacco Tsil gene encoding an EREBP/AP2-type transcription factor enhances resistance against pathogen attack and osmotic stress in tobacco. Plant Cell 13:1035-1046.

Riechmann, J. L., and Meyerowitz, E. M. 1998. The AP2/EREBP family of plant transcription factors. Biol. Chem. 379:633-646.
Rieping, M., Fritz, M., Prat, S., and Gatz, C. 1994. A dominant negative mutant of PG13 suppresses transcription from a cauliflower mosaic virus $35 \mathrm{~S}$ truncated promoter in transgenic tobacco plants. Plant Cell. 6:1087-1098

Sakuma, Y., Liu, Q., Dubouzet, J.-G., Abe, H., Shinozaki, K., and Yamaguchi-Shinozaki, K. 2002. DNA-binding specificity of the ERF/AP2 domain of Arabidopsis DREBs, transcription factors involved in dehydration- and cold-inducible gene expression. Biochem. Biophys. Res. Commun. 290:998-1009.

Salch, Y. P., and Shaw, P. D. 1988. Isolation and characterization of pathogenicity genes of Pseudomonas syringae pv. tabaci. J. Bacteriol 170:2584-2591.

Sambrook, J., Fritsch, E. F., and Maniatis, T. 1989. Molecular cloning: A Laboratory Manual, 2nd ed. Cold Spring Harbor Laboratory Press, Cold Spring Harbor, NY, U.S.A.

Shin, R., Park, J. M., An, J.-M., and Paek, K.-H. 2002. Ectopic expression of Tsi1 in transgenic hot pepper plants enhances host resistance to viral, bacterial, and oomycete pathogens. Mol. Plant-Microbe Interact. 15:983-989.

Solano, R., Stepanova, A., Chao, Q., and Ecker, J. R. 1998. Nuclear events in ethylene signaling: A transcriptional cascade mediated by ETHYLENE INSENSITIVE3 and ETHYLENE RESPONSE FACTOR1. Genes Dev. 12:3703-3714.

Stockinger, E. J., Gilmour, S. J., and Thomashow, M. F. 1997. Arabidopsis thaliana $C B F 1$ encodes an AP2 domain-containing transcriptional activator that binds to the $\mathrm{C}$-repeat/DRE, a cis-acting DNA regulatory element that stimulates transcription in response to low temperature and water deficit. Proc. Natl. Acad. Sci. U.S.A. 94:1035-1040.

Strathmann, A., Kuhlmann, M., Heinekamp, T., and Dröge-Laser, W. 2001. BZI-1 specifically heterodimerises with the tobacco bZIP transcription factors BZI-2, BZI-3/TBZF and BZI-4, and is functionally involved in flower development. Plant J. 28:397-408.

Thara, V. K., Tang, X., Gu, Y. Q., Martin, G. B., and Zhou, J. M. 1999. Pseudomonas syringae pv tomato induces the expression of tomato EREBP-like genes Pti4 and Pti5 independent of ethylene, salicylate and jasmonate. Plant J. 20:475-483.

Tronchet, M., Ranty, B., Marco, Y., and Roby, D. 2001. HSR203 antisense suppression in tobacco accelerates development of hypersensitive cell death. Plant J. 27:115-127.

Valentine, T. A., Roberts, I. M., and Oparka, K. J. 2002. Inhibition of tobacco mosaic virus replication in lateral roots is dependent on an activated meristem-derived signal. Protoplasma 219:184-196.

van der Fits, L., and Memelink, J. 2000. ORCA3, a jasmonate-responsive transcriptional regulator of plant primary and secondary metabolism. Science 289:295-297.

Vernooij, B., Friedrich, L., Morse, A., Reist, R., Kolditz-Jawhar, R., Ward, E., Uknes, S., Kessmann, H., and Ryals, J. 1994. Salicylic acid is not the translocated signal responsible for inducing systemic acquired resistance but is required in signal transduction. Plant Cell 6:959-965.

Wu, K., Tian, L., Hollingworth, J., Brown, D. C., and Miki, B. 2002. Functional analysis of tomato Pti4 in Arabidopsis. Plant Physiol. 128:30-37.

Xue, G. P. 2003 The DNA-binding activity of an AP2 transcriptional activator $H \nu \mathrm{CBF} 2$ involved in regulation of low-temperature responsive genes in barley is modulated by temperature. Plant J. 33:373-383

Yalpani, N., Altier, D. J., Barbour, E., Cigan, A. L., and Scelonge, C. J. 2001. Production of 6-methylsalicylic acid by expression of a fungal polyketide synthase activates disease resistance in tobacco. Plant Cell 13:1401-1410.

Zhou, J., Tang, X., and Martin, G. B. 1997. The Pto kinase conferring resistance to tomato bacterial speck disease interacts with proteins that bind a cis-element of pathogenesis-related genes. EMBO (Eur. Mol. Biol. Organ.) J. 16:3207-3218. 